\title{
Microbiological and Enzymatic Activity of Soil after Pollution with Fluorine
}

\author{
Radosław Szostek $^{1 *}$, Zdzisław Ciećko ${ }^{1,2}$, Maciej Walczak ${ }^{3}$, Maria Swiontek-Brzezinska ${ }^{3}$ \\ ${ }^{1}$ Chair of Environmental Chemistry, University of Warmia and Mazury in Olsztyn, \\ Plac Lodzki 4, 10-727 Olsztyn-Kortowo, Poland \\ ${ }^{2}$ University of Ecology and Management in Warsaw, Faculty of Ecology, \\ Olszewska 12, 00-792 Warsaw, Poland \\ ${ }^{3}$ Department of Environmental Microbiology and Biotechnology, Nicolaus Copernicus University in Torun, \\ Lwowska 1, 87-100 Torun, Poland
}

Received: November 20, 2014

Accepted: September 21, 2015

\begin{abstract}
The objective of this research has been to determine the impact of soil contamination with fluorine, including the concomitant application of substances neutralizing this pollution, on counts of actinomyces, fungi, and copiotrophic bacteria, and on the activity of acid phosphatase, alkaline phosphatase, grease, and dehydrogenase. The research was based on two pot experiments, both conducted in 2009 in a greenhouse at the University of Warmia and Mazury in Olsztyn, Poland. One experiment involved winter oilseed rape, while the other was performed on maize followed by yellow lupine. The following factors were included in both experiments:

I) increasing doses of fluorine in the form of potassium fluoride $\left(0,100,200,300 \mathrm{mgF} \cdot \mathrm{kg}^{-1}\right.$ of soil)

II) substances neutralizing soil pollution with fluorine: lime, in a dose corresponding to $1 \mathrm{Hh}$ of soil, charcoal, and loam - both in amounts equal to $3 \%$ of the soil mass per pot.

The biological activity of soil was assayed after harvesting winter oilseed rape (BBCH 69) and yellow lupine (BBCH 69).

It has been demonstrated that low doses of fluorine (from 100 to $200 \mathrm{mgF} \cdot \mathrm{kg}^{-1}$ of soil) had a positive influence on counts of the analyzed microorganisms and on the activity of the examined soil enzymes. Under the influence of such low amounts of fluorine, the number of actinomyces and the activity of urease increased in soil tested after the harvest of winter rape and yellow lupine, the latter being a catch crop sown after maize. The neutralizing substances had a much better effect on counts of the analyzed microorganisms than on the activity of soil enzymes. The counts of actinomyces and copitrophic bacteria were positively affected by all the substances added to soil, as compared to the control treatments. With respect to fungi, these microorganisms responded positively only to the application of charcoal and loam to soil cropped with yellow lupine. In general, the tested substances had a beneficial influence on the activity of acid phosphatase and urease. As regards the activity of alkaline phosphatase, it was adversely affected by the neutralizing substances. The residual effect of fluorine on counts of the analyzed microorganisms and activity of the soil enzymes was milder in the soil sampled after the harvest of yellow lupine, which seems to indicate that fluorine loses its toxic properties with time.
\end{abstract}

Keywords: fluorine, Lupinus luteus L., Brassica napus L., soil microbiological activity, substances neutralizing soil pollution

\footnotetext{
*e-mail: radoslaw.szostek@uwm.edu.pl
} 


\section{Introduction}

The element fluorine is widespread in the natural environment. In fact, it is the $13^{\text {th }}$ most abundant element in the Earth's crust [1]. The increasing concentration of fluorine in particular compartments of the environment is due to its emission from phosphate fertilizer plants, aluminium smelters and glassworks, steelworks, ceramics factories, and municipal power and heat generating plants [2]. The high concentration of fluorine in the soil environment poses a serious threat to soil-dwelling microorganisms and causes inhibition of some of the soil enzymes [3].

Analysis of the enzymatic activity of soil is one of the most popular 'soil fertility indicators' that support soil quality assessment [4]. Thus, soil enzymes can be treated as indicators suggesting the degree of degradation of a soil environment [5]. Numerous studies have demonstrated that analysis of counts of several microbial groups as well as the activity of certain soil enzymes can provide us with reliable data for an evaluation of soil quality $[6,7]$.

The aim of this study has been to shed light on the impact of soil contamination with fluorine on some microbiological parameters of soil, and on the influence of some neutralizing substances, i.e. lime, charcoal, and loam added to the substrate in order to control the toxic effect of fluorine.

\section{Material and Methods}

Our considerations rely on results of two pot experiments performed in a greenhouse of the University of Warmia and Mazury in Olsztyn, Poland in 2009. The experiments were set up on soil taken from the arable layer of soil, which represented the textural class of loamy sand. The tested plants were winter oilseed rape (Brassica napus L.) and yellow lupine (Lupinus luteus L), which was sown as a catch crop after maize.

Two factors were analyzed. The first order factor included increasing doses of fluorine, used in the form of potassium fluoride to simulate soil contamination, while the second factor involved a comparison of three substances neutralizing the soil contamination with fluorine.

Soil contamination with fluorine in both experiments amounted to $0,100,200$, and $300 \mathrm{mgF} \cdot \mathrm{kg}^{-1}$ of soil.

The substances neutralizing soil pollution with fluorine comprised lime, in a dose corresponding to $1 \mathrm{Hh}$ of soil, and charcoal and loam in amounts making up 3\% of the soil mass in a pot.

In the case of yellow lupine, both fluorine and the neutralizing substances were incorporated into soil only under the main crop, i.e. maize.

In total, each experiment consisted of 16 treatments including three replications. The doses of fluorine and neutralizing substances were mixed with soil at an amount of $9.0 \mathrm{~kg}$ per pot while the experiments were being established. Batches of soil were carefully mixed with appropriate doses of the pollutant and pollution alleviating matter and transferred to pots labelled accordingly. After plant emergence, the seedlings were thinned, leaving 13 plants in each pot. The soil moisture in the pots was maintained at a level of $60 \%$ of water capillary capacity of soil. Plants were harvested after 64 days for the duration of either experiment (BBCH 69).

Soil samples for microbiological and enzymatic assays were taken from the pots immediately after the harvest of two of the tested plants. The samples were then placed in sealed containers and kept in a refrigerator. Before analyses, the soil was dried and passed through a $1 \mathrm{~mm}$ sieve. Then the following determinations were made: counts of heterotrophic bacteria on TSA medium, counts of actinomyces on the Pochon medium [8], counts of fungi on the Sabouraud medium [9], activity of acid and alkaline phosphatases with the fluorimetric method (using fluorescencelabelled, organic MUF-phosphate substrate [10-12]), the activity of dehydrogenase by the photometric method according to Dojlido et al. [13], and the activity of urease by the photometric method (the concentration of $\mathrm{NH}_{4}^{+}$ions was determined by the nesslerization method).

Incubation was carried out at $28^{\circ} \mathrm{C}$. The number of aerobic heterotrophic bacteria was determined after 72 hours; the number of filamentous bacteria was assayed after five days of incubation, and the number of actinomyces was tested after seven, 14, and 21 days of incubation. The results are given in c.f.u. per $1 \mathrm{~kg}$ of soil. All microbiological determinations were performed in three parallel replications on each soil sample.

The results underwent statistical processing using the software application Statistica [14], and two-factor analysis of variance ANOVA, while the least significant differences (LSD) were determined according to Duncan's test at a level of significance of $\alpha=0.05$.

\section{Results and Discussion}

The results showed that not all groups of microorganisms responded in a similar way to soil contamination with fluorine (Fig. 1).

With respect to actinomyces, the growing degree of soil contamination with fluorine was shown to have produced a positive effect on the counts of these microorganisms in soil, both after winter oilseed rape and yellow lupine harvest. In soil after the harvest of winter oilseed rape, the subsequently higher levels of soil contamination with fluorine contributed to a steadily growing count of actinomyces, hence in the soil polluted with the highest dose of fluorine (i.e. $300 \mathrm{mgF} \cdot \mathrm{kg}^{-1}$ of soil), their number was $95 \%$ higher than in the pots free from fluorine pollution. Out of the three neutralizing substances, charcoal had the most favorable effect on the abundance of actinomyces. In soil after the harvest of yellow lupine, the highest count of these organisms was detected when the medium dose of fluorine was applied (200 $\mathrm{mgF} \cdot \mathrm{kg}^{-1}$ of soil), in which case it was $34 \%$ higher than the count of actinomyces in the control variant. Regarding the neutralizing substances, lime was the strongest inhibitor of the negative influence of fluorine on counts of actinomyces. In conclusion, higher counts of 
actinomyces were found in soil previously cropped with yellow lupine (after maize) than in soil under winter oilseed rape.

Another group of microorganisms whose counts were measured in this study was composed of copiotrophic bacteria. In both soils, the number of these cells was highly varied by the increasing soil contamination with fluorine. In soil sampled after the harvest of oilseed rape, the count of copiotrophic bacteria increased gradually as the degree of soil pollution with fluorine increased, although the bacterial growth continued only up to a certain level. Thus, at the highest dose of the pollutant, a slight decrease in the count of copiotrophic bacteria occurred, although the result was approximately the same as that obtained in the control treatment. Fluorine produced a reverse effect on copiotrophic bacteria in soil under yellow lupine. The results of our determinations implied that the count of these bacteria generally decreased in response to the increasing doses of fluorine in soil. The most severe soil contamination with this element caused a $28 \%$ decline in the count of copiotrophic bacteria relative to the control. Among the three neutralizing substances, in soil after oilseed rape as well as yellow lupine harvest, charcoal had the most beneficial influence on the growth and development of these bacteria.

The results of our analyses suggest that a higher number of copiotrophic bacteria was noted in soil cropped with yellow lupine (the residual effect) than with winter oilseed rape.

The final group of microorganisms we focued on consisted of fungi. The results of these determinations evidenced that soil pollution with fluorine strongly modified and varied the abundance of fungi in soil after the harvest of both winter oilseed rape and yellow lupine. The number of fungi in soil under winter oilseed rape was found to have increased under the influence of the growing doses of fluorine. In this experiment, changes in the abundance of fungi against the background of growing fluorine doses followed a parabolic pattern. Our analysis of the means demonstrates that the dose of $200 \mathrm{mgF} \cdot \mathrm{kg}^{-1}$ of soil had the most stimulating effect on the growth and development of fungi. In turn, a reverse relationship was observed in soil cropped with yellow lupine, i.e. there was a gradual decrease in the number of fungi as the degree of soil contamination with fluorine increased. Thus the object polluted with $300 \mathrm{mgF} \cdot \mathrm{kg}^{-1}$
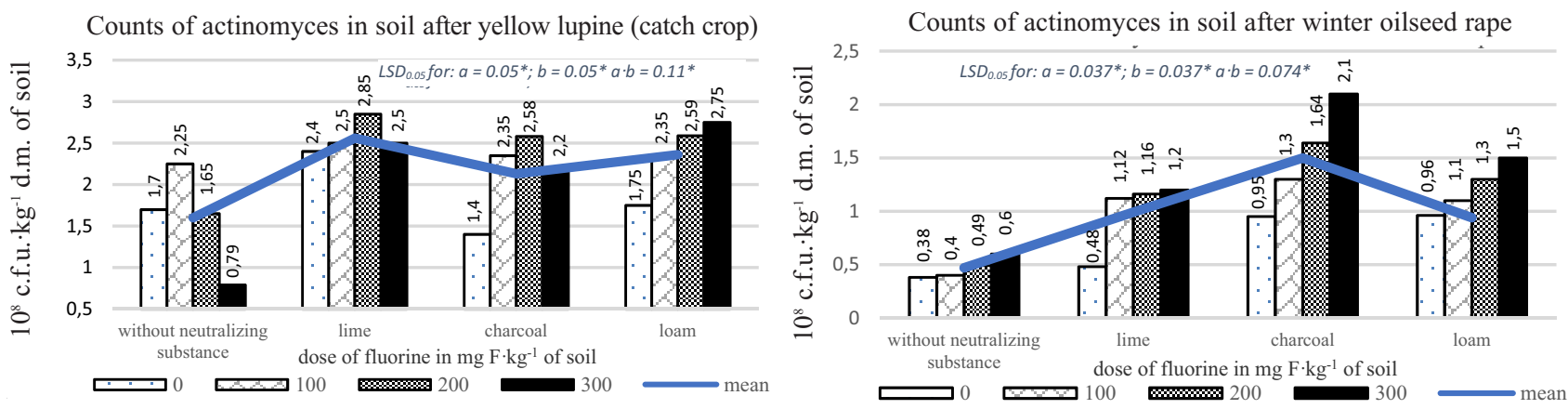

Counts of copiotrophis bacteria in soil after yellow lupine (catch crop)

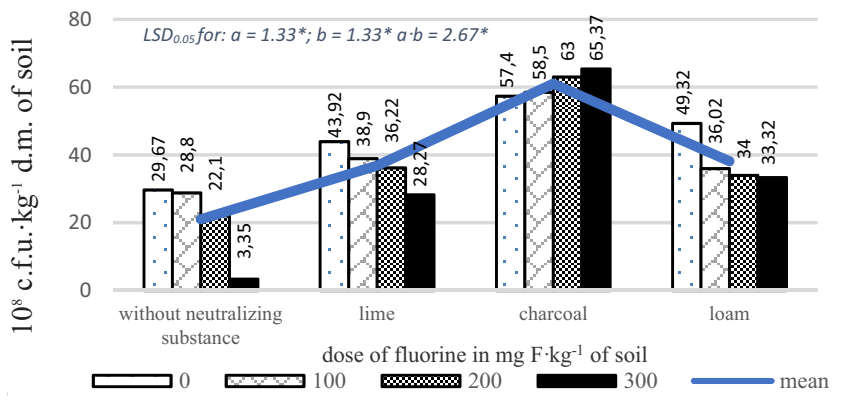

Counts of copiotrophis bacteria in soil after winter oilseed rape

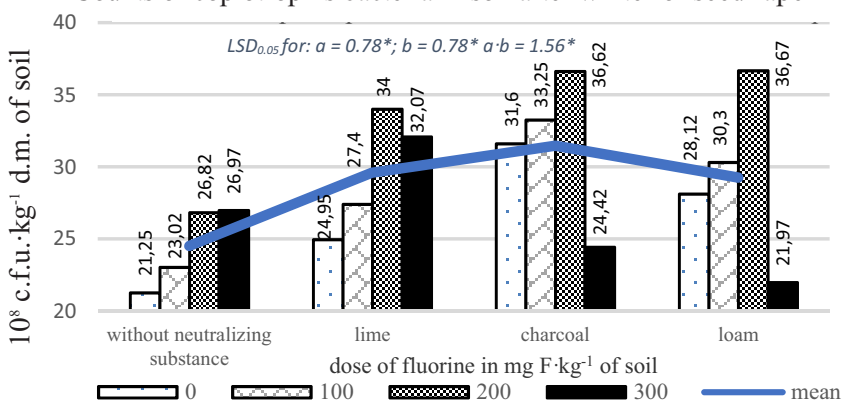

Counts of fungi in soil after yellow lupine (catch crop)

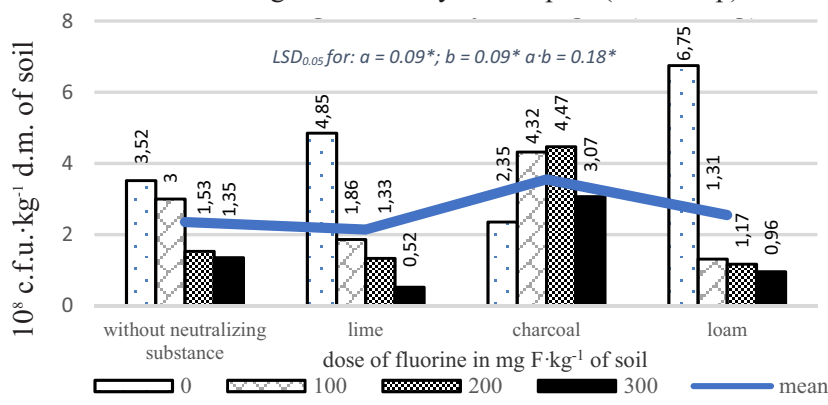

Counts of fungi in soil after winter oilseed rape

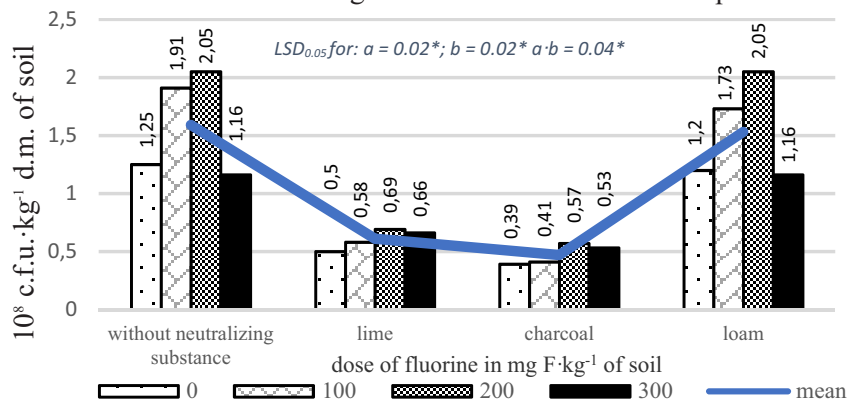

Fig. 1. Counts of actinomyces, bacteria, and fungi in soil after harvesting yellow lupine and winter oilseed rape, depending on fluorine dose and neutralizing substance.

$\mathrm{a}$ - dose of fluorine; $\mathrm{b}$ - type of neutralizing substance; ${ }^{*} \mathrm{p}$ - significant at 0.05 ; c.f.u. - colony forming unit 
of soil was determined to contain $64 \%$ less of fungi than the control object. Our comparison of the counts of fungi in soil after the harvest of both plants shows that there were fewer fungi in soil under winter oilseed rape than under yellow lupine. Evdokimova and Korneykova [3] demonstrated a decrease in the number of fungi, including Aspergillus niger spp., in soil contaminated with fluorine.

In general, counts of all the analyzed microorganisms were higher in soil cropped with yellow lupine (the residual effect) than with winter oilseed rape.

Soil pollution with fluorine also affected soil enzymatic activity (Fig. 2).

The activity of acid phosphatase in the analyzed soils was highly varied by the increasing degree of soil pollution with fluorine. In soil sampled after the harvest of winter oilseed rape, the activity of acid phosphatase was generally increasing alongside increasing soil pollution with fluorine, although the effect was observed only up to a certain level of soil contamination. Thus the highest dose of fluorine introduced to soil resulted in a considerable depression of the activity of acid phosphatase, which on average equalled
$31 \%$ relative to control. Of the substances added to soil in order to inactivate the negative influence of fluorine, charcoal was most effective. The soil cropped with yellow lupine was found out to demonstrate a higher activity of acid phosphatase in response to the increasing soil pollution with fluorine. However, the control series and the one with charcoal were an exception, because the highest fluorine dose led to a slight decline in the activity of this enzyme, which nevertheless continued to resemble that recorded in the unpolluted soil (control). Out of the three neutralizing substances, loam had the most favorable impact on the activity of acid phosphatase. The averaged values of the activity of this enzyme implicate that soil under yellow lupine (a catch crop after maize) was characterized by a higher activity of acid phosphatase. Also, Walker [15] showed that the activity of phosphatases was depressed by increasing levels of fluorine.

The current results show that an increasing level of soil contamination with fluorine strongly modified and varied the activity of alkaline phosphatase in soil, both under winter oilseed rape and yellow lupine. Regarding the activity
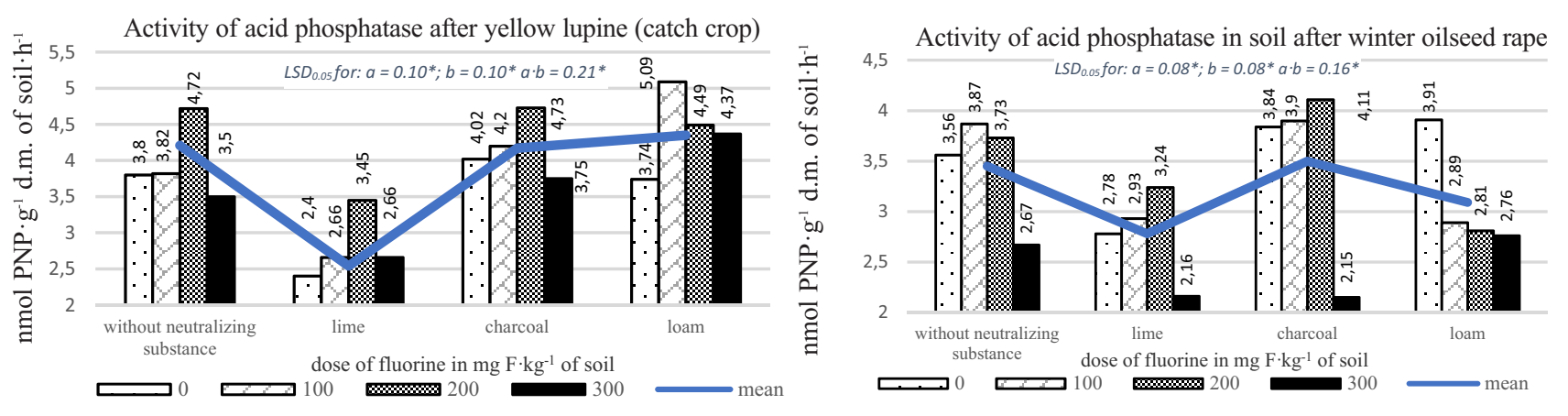

Activity of alkaline phosphatase after yellow lupine (catch crop)

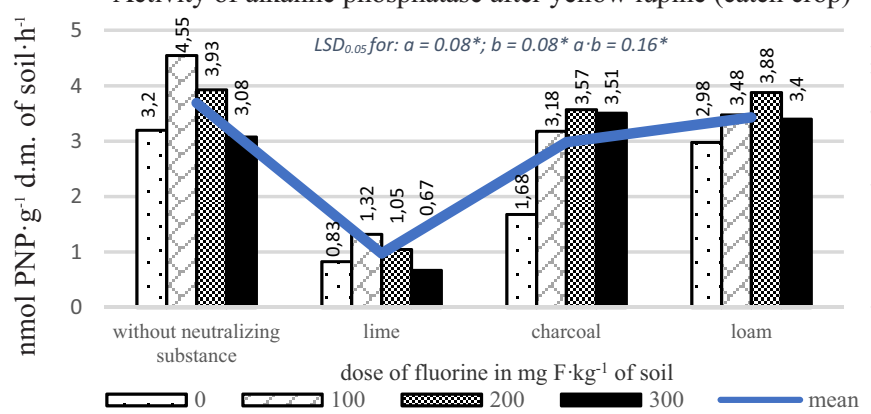

Activity of alkaline phosphatase in soil after winter oilseed rape
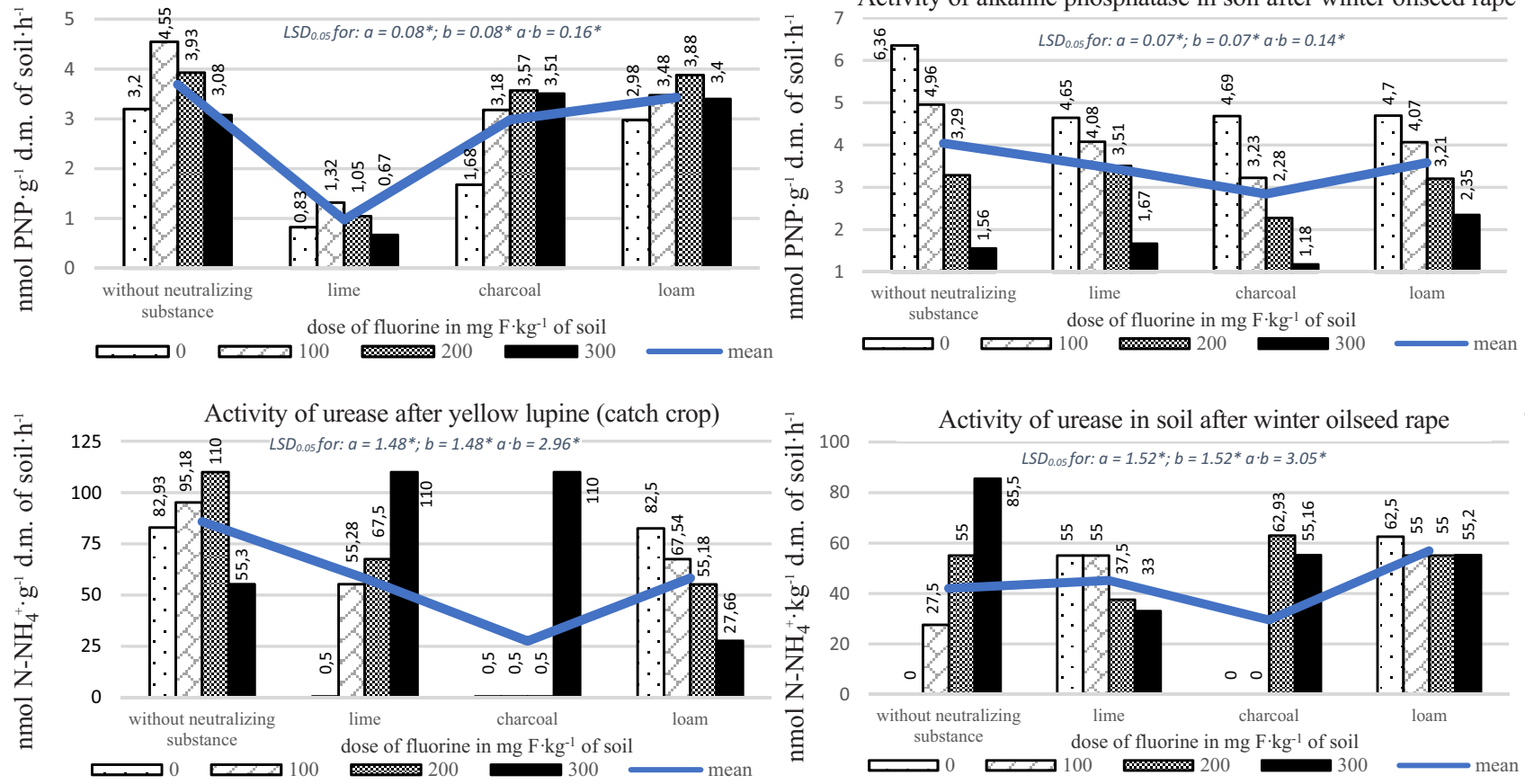

Fig. 2. Activity of acid phosphatase, alkaline phosphatases, and urease in soil after harvesting of yellow lupine and winter oilseed rape, depending on fluorine dose and neutralizing substance.

$\mathrm{a}$ - dose of fluorine; $\mathrm{b}$ - type of neutralizing substance; ${ }^{*} \mathrm{p}$ - significant at 0.05 ; PNP - p-nitrophenol 
of alkaline phosphatase in soil from which winter oilseed rape was harvested, the increasing soil pollution with fluorine had a negative effect on the analyzed enzyme. Under the influence of soil contamination with this element, a linear decrease in the activity of alkaline phosphatase was observed on the background of the growing soil pollution with fluorine. Thus the object polluted with $300 \mathrm{mgF} \cdot \mathrm{kg}^{-1}$ of soil presented the average activity of alkaline phosphatase $67 \%$ lower than in the control. Reversely, in soil under yellow lupine, all the tested doses of fluorine had a positive influence on the activity of alkaline phosphatase. Our analysis of the means suggests that the doses of 100 and $200 \mathrm{mgF} \cdot \mathrm{kg}^{-1}$ of soil had the most beneficial effect on the activity of alkaline phosphatase. In sum, a higher activity of this enzyme was found in soil after the harvest of yellow lupine than winter oilseed rape. In both series of the experiment, the addition of loam most strongly buffered the negative effect of fluorine on the activity of alkalaine phosphatase. Smolik et al. [16] noticed that the activity of acid phosphatase and $\beta$-glucosidase increased by 8 and $18 \%$, respectively, in response to a dose of $190 \mathrm{mgF} \cdot \mathrm{kg}^{-1}$ of soil. Under the same dose, the activity of alkaline phosphatase was $5 \%$ lower and that of urease was depressed by $18 \%$ compared to objects not polluted with sodium fluoride. On the other hand, when the pollution reached $950 \mathrm{mgF} \cdot \mathrm{kg}^{-1}$ of soil, complete inhibition of all the analyzed soil enzymes was noticed, relative to the control. Poulsen [17] and Walker [15] confirm the negative effect of soil contamination with fluorine on the activity of phosphatases in soil. The adverse effect of fluorine compounds on the activity of acid and alkaline phosphatases, dehydrogenase, and urease was also reported by Pati and Sahu [18]. Telesiński et al. [19] proved that the activity of acid and alkaline phosphatases was significantly positively correlated with the content of both soluble and potentially phytoavailable fluorine, while the activity of dehydrogenases was negatively correlated only with the soil content of soluble fluorine. It was also observed that changes in the activity of phosophatases mainly depended on the content of fluorine, which is potentially accessible to plants. Besides, the activity of phosphatases as well as other extracellular enzymes is significantly affected by the presence of organic matter. Swiontek-Brzezinska et al. [20] analyzed the impact of a soil-willow filter operating in a local wastewater treatment system on the activity of extracellular enzymes, noticing the highest activity of phosphatases, aminopeptidase, and $\alpha$ and $\beta$-glucosidase at a site where sewage and wastewater from the household were discharged. Further away from that site, the activity of all the enzymes was declining.

Our results revealed a positive effect of the increasing soil contamination with fluorine on the activity of urease in soil. Such a positive relationship was confirmed for the activity of urease in soil under both winter oilseed rape and yellow lupine. The highest average activity of urease in soil after the harvest of winter oilseed rape or yellow lupine was observed in the pots polluted with the highest dose of fluorine, which indicates that this enzyme is considerably tolerant to the soil contamination by this xenobiotic element.
Our comparative assessment of the three neutralizing substances shows that the activity of urease in soil after the harvest of winter oilseed rape was most positively affected by loam. The inhibitory influence of fluorine on the activity of catalase and urease in soil was also demonstrated by Marquis et al. [21]. In brief, the averaged values of the activity of urease in soil after the harvest of both crops support the conclusion that the highest activity of this enzyme occurred in soil after the harvest of yellow lupine.

In our experiments, the soil enzyme dehydrogenase proved to be highly sensitive to soil contamination with fluorine. In all the variants of the experiments, irrespective of the applied dose of fluorine or substances neutralizing this pollutant, complete inhibition of dehydrogenases in soil was observed. Therefore, the article does not contain data on the activity of these enzymes. Sinclair et al. [22] report diminishing activity of dehydrogenase in soil polluted with fluorine. Langer and Günther [23] confirm the negative effect of high doses of fluorine on the activity of dehydrogenases and arylsulphatase. Nowak et al. [24] concluded that the inhibition of the activity of dehydrogenases, phosphatases, and $\beta$-glucosidase was significantly positively correlated with the content of soluble and potentially phytoavailable fluorine in various soils. Among the analyzed soil enzymes, the highest correlation coefficient was determined for $\beta$-glucosidase. Tscherko and Kandeler [25] achieved high coefficients of the correlation between the soil content of fluorine and the activity of dehydrogenase and arylsulphatase, which equalled -0.86 and -0.84 , respectively. The same researchers noted a decreased activity of dehydrogenase under a dose of fluorine as low as $100 \mathrm{mgF} \cdot \mathrm{kg}^{-1}$ of soil, while arylsulphatase was even more sensitive - responding negatively to just $20 \mathrm{mgF} \cdot \mathrm{kg}^{-1}$ of soil. Kolesnikov et al. [26], who investigated the effect of soil contamination with fluorine, boron, selenium, and arsenic demonstrated an inhibited activity of dehydrogenase, invertase, and catalase in soil. Garcia-Gil et al. [27] also confirm that the enzymatic activity of soil - including such soil enzymes as dehydrogenase, phosphatase and urease - decreases in response to increasing soil contamination by fluorine.

\section{Conclusions}

1. The effect of increasing soil contamination with fluorine on counts of microorganisms and soil enzymatic activity depended on the species of plant, the dose of fluorine introduced to soil, and an applied substance neutralizing the pollutant.

2. The effect of incremental doses of fluorine polluting soil on the microbiological and biochemical properties of soil was not unidirectional. In general, low doses of fluorine contributed to an increase in the number of the analyzed microorganisms and the activity of the analyzed soil enzymes. However, it should be emphasized that in both experiments soil contamination with fluorine had the most equivocal influence on the counts of actinomyces and the activity of urease. 
3. The neutralizing substances incorporated into soil had a more positive effect on counts of microorganisms than on the enzymatic activity of soil. All the applied substances affected positively the counts of actinomyces and copiotrophic bacteria as compared with the control. With respect to fungi, they presented a positive response only in soil previously cropped with yellow lupine and enriched with charcoal and loam. In general, the neutralizing substances added to soil had a positive effect on the activity of acid phosphatase and urease. As for alkaline phosphatase, the neutralizing substances had a negative influence on the activity of this enzyme.

4. The residual effect of fluorine on counts of the analyzed microorganisms and enzymatic activity of soil was milder in soil after the harvest of yellow lupine, leading us to the conclusion that fluorine loses its toxic properties with time.

\section{References}

1. OCHOA-HERRERA V., BANIHANI Q., LEON G., KHATRI CH., FIDEL AJ., SIERRA-ALVAREZ R. Toxicity of fluoride to microorganisms in biological wastewater treatment systems. Water Res., 43, 3177, 2009.

2. BOMBIK E., BOMBIK A., GÓRSKI K., SABA L., BOMBIK T., RYMUZA K. The effect of environmental contamination by fluorine compounds on selected horse tissues. Pol. J. Environ. Stud., 20, (1), 37, 2011.

3. EVDOKIMOVA G.A., KORNEYKOVA V.M. Microfungal communities in soil polluted with fluoride. Nat. Sci., 2, (9), 1022, 2010.

4. KLIKOCKA H., NAROLSKI B., KLIKOCKA O., GŁOWACKA A., JUSZCZAK D., ONUCH-AMBORSKA J., GAJ R., MICHAŁKIEWICZ G., CYBULSKA M., STEPANIUK S. The effect of soil tillage and nitrogen fertilization on microbiological parameters of soil on which spring triticale is grown. Pol. J. Environ. Stud. 21, (6), 1676, 2012.

5. MAKOI J., NDAKIDEMI P.A. Selected soil enzymes: Examples of their potential roles in the ecosystem. Afr. J. Biotechnol., 7, (3), 181, 2008.

6. BIELIŃSKA E.J., PRANAGAL J. Enzymatic activity of soil contaminated with triazine herbicydes. Pol. J. Environ. Stud., 16, (2), 295, 2007.

7. BIELIŃSKA E.J., MOCEK-PŁÓCINIAK A., KACZMAREK Z. Eco-chemical forest soil indices from a forest fire. Pol. J. Environ. Stud., 17, (5), 665, 2008.

8. KAŃSKA Z., GRABIŃSKA-ŁONIEWSKA A., ŁEBKOWSKA M., ŻECHOWSKA E. Laboratory exercises in biology sanitary. Warsaw Uniwersity of Technology, 193 pp., Warsaw, 2001 [In Polish].

9. GRABIŃSKA-ŁONIEWSKA A. Laboratory exercises in general microbiology. Warsaw Uniwersity of Technology, pp. 223, Warsaw, 1999 [In Polish].

10. FREEMAN C., LISKA G., OSTLE J.N., JONES E.S., LOCK A.M. The use of fluorogenic substrates for measuring enzyme activity in peatlands. Plant Soil., 175, 147, 1995.
11. MARX M.C., WOOD M., JARVIS S.C. A microplate fluorometric assay for the study enzyme diversity in soils. Soil Biol. Biochem., 33, 1633, 2001.

12. NIEMI R.M., VEPSÄLÄINEN M. Stability of the fluorogenic enzyme substrate and $\mathrm{pH}$ optima of enzyme activities in different finnish soils. J. Microbiol. Meth., 60, 195, 2005.

13. DOJLIDO J., DOŻAŃSKA W., HERMANOWICZ W., KOZIOROWSKI B., ZERBE J. Physico-chemical water testing. Arkady Press, Warsaw, pp. 556, 1999 [In Polish].

14. STATSOFT, INC. 2010. STATISTICA (data analysis software system), version 10.0. www.statsoft.com.

15. WALKER A.T. Influence of volcanic ash on Andosols in Iceland. Master's Thesis, Department of Soil Science, University of Aberdeen: pp. 14, 2010.

16. SMOLIK B., NOWAK J., KŁÓDKA D., SZYMCZAK J., TELESIŃSKI A. Determination of humus usefulness in limiting on adverse influence of fluoride on some soil hydrolases activity in a laboratory experiment. Zesz. Probl. Post. Nauk Rol., 537, 337, 2009 [In Polish].

17. POULSEN R. The effects of fluoride pollution on soil microorganisms. 10 ECTS thesis in partial fulfilment of a Baccalaureus Scientiarum degree in biochemistry, Reykjavik pp. 44, 2011.

18. PATI S.S., SAHU S.K. Effect of fluoride on $\mathrm{CO}_{2}$ evolution and dehydrogenase activity in soil. Cytobios 94, (375), 7, 1998.

19. TELESIŃSKI A., MUSIK D., SMOLIK B., KŁÓDKA D., ŚNIOSZEK M., SZYMCZAK J., GRABCZYŃSKA E. An attempt to determine the correlation between enzymatic activity and fluorine content in forest soils affected by emission from Police Chemical Plant. L: Ecotoxicology in environmental protection, (Ed.) Kołwzan B., Grabas K., 421, 2008 [In Polish].

20. SWIONTEK-BRZEZINSKA M., LALKE-PORCZYK E., KALWASIŃSKAA. Extracellular enzyme activity in a willow sewage treatment system. Curr. Microbiol., 65, 776, 2012.

21. MARQUIS R.E., CLOCK S.A., MOTA-MEIRA M. Fluoride and organic weak acids as modulators of microbial physiology. FEMS Microbiol. Rev., 26, (5), 493, 2003.

22. SINCLAIR D.C.R., SMITH G.M., STAINES B.H.J. Soil dehydrogenase activity adjacent to remedially treated timber, weathered in a physical field model. Int. Biodeter. Biodegr., 39, (2/3), 207, 1997.

23. LANGER U., GÜNTHER T. Effects of alkaline dust deposits from phosphate fertilizer production on microbial biomass and enzyme activities in grassland soils. Environ. Pollut., 112, (3), 321, 2001.

24. NOWAK J., SMOLIK B., ZAKRZEWSKA H. Relations between fluorine content in soil and inhibition of soil enzymes activity. Electron. J. Pol. Agric. Univ. Ser. Environ., 8, (2), 2005. (http://www.ejpau.media.pl/volume8/ issue $/$ art-15.html).

25. TSCHERKO D., KANDELER E. Ecotoxicological effects of fluorine deposits on microbial biomass and enzyme activities in grasslands. Eur. J. Soil Sci., 48, 329, 1997.

26. KOLESNIKOV S.I., POPOVICH A.A., KAZEEV K.S., VAL'KOV V.F. The influence of fluorine, boron, selenium and arsenic pollution on the biological properties of ordinary chernozems. Eurasian. Soil Sci., 41, (4), 400, 2008.

27. GARCIA-GIL J.C., KOBZA J., SOLER-ROVIRA P., JAVOREKOVA S. Soil microbial and enzyme activities response to pollution near an aluminium smelter. Clean Soil Air Water, 41, (5), 485, 2013. 